
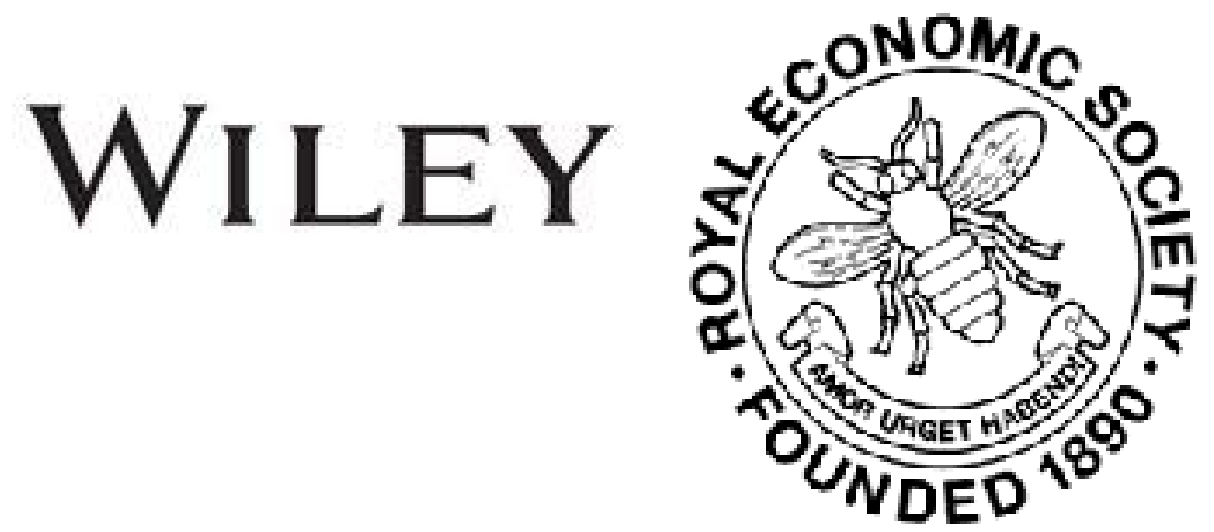

\title{
An Export Duty on Coal
}

\section{Author(s): Alfred Marshall}

Source: The Economic Journal, Vol. 11, No. 42 (Jun., 1901), pp. 265-267

Published by: Wiley on behalf of the Royal Economic Society

Stable URL: http://www.jstor.org/stable/2957171

Accessed: 27-06-2016 06:45 UTC

Your use of the JSTOR archive indicates your acceptance of the Terms \& Conditions of Use, available at

http://about.jstor.org/terms

JSTOR is a not-for-profit service that helps scholars, researchers, and students discover, use, and build upon a wide range of content in a trusted digital archive. We use information technology and tools to increase productivity and facilitate new forms of scholarship. For more information about JSTOR, please contact support@jstor.org.

Wiley, Royal Economic Society are collaborating with JSTOR to digitize, preserve and extend access to The Economic Journal 
result would be a succession of deformed budgets, balanced some by enormous deficiencies and others by an equally abnormal bonus. It would be the reign of disorder, and from this disorder harmony was expected to proceed. If the proposed scheme is sound, it ought to be logically granted to every kind of agricultural and industrial produce. Wine growers have already claimed the same advantages for themselves; premiums on the export of spirits and of cattle could no longer be consistently denied. And when every variety of agricultural produce had had its turn, metallurgy, which also suffers from an excess of production, would naturally insist on having its own. The consequence would be the creation of an infinity of taxes, utterly crushing every class, as well in its producing as in its consuming capacity.

The Bill was rejected by 176 votes against 103 . It is interesting to notice the totally undogmatical and strictly matter of fact arguments by which its defeat was brought about.

E. CASTELOT

\section{An Export Duty on Coal.}

THE following letters from Professor Marshall to the Times (published April 22 and May 9), relating to a question of present practical importance and permanent theoretical interest, appear worthy of being reprinted in the Economic Journal :

Sir,--The Chancellor of the Exchequer's proposal to put an export duty on coal is certainly not free from difficulties. But I venture to submit the opinion that it is not, as some have asserted, to be condemned on general economic principles. The incidence of export duties is too intricate to be examined fully in your columns. But the main upshot is, I believe, as follows :-

A universal tax on all a country's exports has similar results to those of a universal tax on her imports. Each of them acts in the same way as a special stamp duty on contracts made in connexion with her foreign trade; or, again, as an increase in the cost of carriage across her frontiers (the cost of carriage elsewhere not being affected). Each of them tends to make her goods a little more scarce than they otherwise would be in foreign markets; and so to enable an all-round merchant to bring back a trifle more imports in return for each bale of exports. The main burden of such taxes is borne by the country herself, but other countries are forced to contribute a small share.

To the extent of this small share duties on imports and exports show a balance of advantage, from the purely national point of view, as compared with other methods of levying revenue. And free trade would be a blunder if no one were hurt by taxes except those who ultimately pay them.

But nearly all taxes, and especially taxes on commodities and most especially "differential" taxes levied on goods passing the frontiers, 
injure people who do not pay them as well as those who do. For they divert direct consumption from those routes by which human efforts can satisfy human wants most easily; and turn it to others which are naturally less advantageous, but which evade the tax. In so far as this is is done, the people suffer and the tax-gatherer gets nothing. If, for instance, in consequence of the charges imposed when passing the frontier, imported wool were partially displaced by home-grown wool of inferior quality, or at a higher cost, then those who used this wool would be injured by the tax, though they did not help to pay it.

There is no absolute a priori proof that these evils must necessarily outweigh the advantages of shifting a part of the direct burden of a country's taxes on foreigners. And it is not by trained economistsnot even by those who are the most ardent free-traders-that the defence of free trade is based on absolute a priori reasoning.

On the contrary, it is based on a study of details. For that shows that as the world is constituted, an attempt to make other nations contribute to a country's revenue on any considerable scale is foredoomed to failure; and especially that England cannot now do it. Again, a study of detail shows that the waste and friction and indirect consumer's loss caused by differential duties on the frontier are always greater than they appear at first sight; and especially in the case of a densely-peopled country which has limited natural resources and must trust mainly to a highly efficient organisation of her industry and trade.

One may indeed amuse one's self by imagining a small country, whose sole exports consist of rare minerals which other countries are ready to buy from her at almost any cost. She might restrict her output, or levy high duties either on her exports or her imports. All three courses would come to much the same in the long run, and, in any case, she would enrich herself at the expense of her neighbours by refusing free trade.

But as this world is made, no case of this kind on a large scale is possible. There is not, and there cannot be, any large country the greater part of whose exports are free from effective competition. And, therefore, a heavy general tax either on a country's imports or on her exports would merely make foreigners take out their purchases frorn her in those goods which were important for them, and they would supply themselves with other goods from elsewhere. That is, she would fail in the attempt to make scarce those goods for which foreigners have so urgent a need that they would buy them of her at a high cost rather than dispense with them.

There are thus three classes of frontier taxes which may be economically defensible. First come non-differential import duties on comforts and luxuries, such as those in England on tobacco and spirits; and, in case of need, on tea and sugar. Second come "protective" import duties on things for the production of which a country has great latent facilities that are just ripe for development; as was the case. 
with tin-plates in America a fèw years ago. (I am not advocating such taxes, for I believe their end can be attained at less cost in other ways.) The third are special export duties on commodities with which foreigners cannot easily dispenise; such seems to be the case with our best steam coal, and, perhaps, our best gas coal.

If Glamorganshire were an independent country, she might possibly gain by an all-round tax either on imports or on exports. But, as it is, the easiest way in which we can charge to foreigners " all that the traffic will bear" as regards Welsh coal is by a special export duty.

But is it worth while to do this? On the one hand, our coal is a chief foundation of our industrial wellbeing; we are wasting our children's inheritance; and there is much to be said for taking toll from coal in order to lessen our National Debt. On the other hand, a tax on the export. of coal appears to present many technical difficulties ; and to be not worth the disturbance it must cause unless it is to be permanent. And, what is more important, it is, to a certain extent, a breach of international comity; wliile we are in a specially defenceless position against some export duties that certain other countries might conceivably levy. It is now five and twenty years since I first thought of writing to advocate an export duty on coal, but was restrained by this last consideration; and I have often taken up the question since. My doubts have never been. resolved; but I admire the courage of the Chancellor.

Yours faithfully,

ALFRED MARSHALL

Cambridge, April 19.

TO THE EDITOR OF “THE TIMES."

SIR,- It is true that, as Mr. Lambton said in the House yesterday, the late Professor Fawcett wrote in 1879 strongly condemning the proposal to impose an export duty on coal. But I believe that some remonstrances were addressed to him (I happen to know of one), and he modified his position somewhat. His book on "Free Trade and Protection" met a want of the time and quickly passed through several editions. I have not access to the second and third. But in the fourth, published in 1881, he significantly omits the statement, made in 1879, that " a certain quantity of American coal is at the present time being sent to Europe, and it is confidently anticipated by the people of the United States that they will be able in future greatly to extend this trade." He no longer speaks of an export duty as "destroying the foreign demand for English coal," but he holds that it would lead France to supply her wants from the neighbouring Westphalia and Belgium.

Of course the full importance of the superior strength of the best Welsh coal was not recognised at that time, when ships of war were still content with a relatively low rate of speed. And the share of the 